\title{
Development and Evaluation of the Internal Cladding Process of API 5L X70 Risers with Nickel-based superalloy 625 via PTA Welding
}

\author{
Régis Henrique Gonçalves e Silva ${ }^{1}$, Rafael Gomes Nunes Silva ${ }^{2}$, \\ Júlia Moraes Dornelles ${ }^{1}$, Fernando Costenaro Silva ${ }^{1}$
}

\author{
${ }^{1}$ Universidade Federal de Santa Catarina, Department of Mechanical Engineering, Welding and Mechatron- \\ ics Institute - LABSOLDA, CEP: 88040-900, Florianopolis, SC, Brasil. \\ ${ }^{2}$ Belgian Welding Institute - BWI, 9052, Ghent, Belgium. \\ e-mail: rafaelnunes.mat@hotmail.com
}

\begin{abstract}
The Oil and gas exploration is one of the most strategic industrial sectors in the Brazilian economy. The discovery of deep water reserves adds more difficulty to the already problematic use of materials in equipment in extremely corrosive environments. With the objective of increasing the service life of the equipment, and consequently reducing the cost of maintenance and preventing against environmental catastrophes, it is common to use CRA claddings via welding processes, in which the nickel superalloy coatings stand out via the PTA welding process. In this context, the operation of internal cladding of risers becomes extremely complex due to the operational and metallurgical requirements imposed by the application. The present work aims at the development and empirical evaluation of the internal cladding procedure of risers with Nickelbased superalloy 625 via PTA welding process. From tests of cladding on plate, satisfactory preliminary parameters were reached for the performance of internal cladding tests on risers. From the adaptation of the welding parameters, comparative analyzes of three different procedures were carried out, with different weaving amplitude. Visual analysis and inspections were carried out via penetrating liquid and radiography, confirming the welding quality of all procedures performed. Still, proving the metallurgical quality of the developed procedures, analysis of chemical composition was carried out via EDX, presenting satisfactory results. Finally, a financial comparison of the process was elaborated, showing comparatively the consumption of powder and gas, and the time needed for internal cladding.
\end{abstract}

Keywords: Coating; CRA; Nickel Alloy; Pipeline; Plasma Transferred Arc.

\section{INTRODUCTION}

The exploration of Oil and Gas reserves represents one of the main pillars of Brazil's national economy. The discovery of petroleum reserves on the pre-salt layer favored the emergence of new challenges and technologies for manufacturing equipment for its exploration and transport [1]. Although they are the largest source of oil in Brazil [2], the reserves are located approximately $300 \mathrm{~km}$ from the Brazilian coast and in depths of approximately $7 \mathrm{~km}$ below sea level [3]. Due to its geological features, the pre-salt Oil and Gas exploration takes the form of offshore drilling, which demands a high level of technological development and innovative capacity in the whole extraction process [4]. Among the challenges encountered in the extraction of oil, the resistance of the metallic pipelines to the maritime and aggressive environment of the pre-salt stands out.

Risers are pipes that connect a floating offshore production structure, or drilling platform, to a subsea system for productive purposes, such as drilling, production, injection and export of oil. When there is any type of damage, the downtime required for constant corrective maintenance significantly increases the cost of the operation. Thus, preventive maintenance is usually performed, through the internal and external cladding of structures and equipment exposed to wear. In applications with higher corrosion resistance requirements, for example subsea risers, the most used material in the manufacturing of pipelines is the API 5L X70 grade steels [5], while the CRA filler material is generally made of nickel (Ni) superalloys, such as Nickel-based superalloy 625 and 825 [6].

Inconel 625, a nickel-based non-magnetic super alloy consisting of nickel-chromium-molybdenum, has high corrosion resistance and excellent mechanical properties [7, 8]. Chromium prevents corrosion by form- 
ing a layer of $\mathrm{Cr} 2 \mathrm{O} 3$, and molybdenum provides resistance to crevice and pitting corrosion [9]. The Inconel high strength is mainly due to solid solution hardening effect of refractory metals, niobium and molybdenum in a FCC austenitic $\gamma$ matrix. Besides that, the good ductibility which accounts for its non-susceptibility to cracking upon solidification and contraction after welding $[10,11]$. These properties make it a material suitable for surface modification of oil and gas components, especially those made with high-strength and low alloy (HSLA) steel. The HSLA steels, as the API 5L X70, are the most widely used material in the manufacturing of pipelines due its good combination of high mechanical strength, with good toughness, ductility and weldability [12].

Among the welding processes used to carry out the internal cladding of the risers, the Plasma Transferred Arc (PTA) process stands out, being widely used in API 5L X70 cladding applications with Ni-alloys [13] in many industrial areas including chemical processing, nuclear power plants, marine engineering and oil and gas industry, mainly involving corrosion and/or heat resistance [14-17]. The PTA process is characterized by a high metallurgical quality due to a greater microstructural refining [18-20], to the versatility of developing new alloys due to the flexibility of manipulating the chemical composition by mixing powders $[21,22]$ and making composite cladding in which there is a ductile metal matrix and a high hardness material [23-25]. Besides these, the PTA process has as operational benefits the smoothness of the deposition of powder without causing oscillation in the melting pool, absence of spatters, independence between heat input and material deposition rate, besides the coaxiality of the powder injection, allowing a high control of the melting pool and the geometry and finish of the cladding [26, 27]. In addition, PTA process can achieve very low dilution, $5 \%$ to $10 \%$, if compared with other arc welding process, $20 \%$ to $25 \%$ [12]. This feature combined with high energetic efficiency of PTA leads to a single-layer thick coatings that exhibit microstructural properties characteristic of a bulk material, independent of the substrate properties, that is, the lower the dilution, the less Inconel 625 is necessary to obtain the same corrosion resistance [28].

Due to the high demand for solutions and the need to increase the service life of the pipelines that transport Oil and Gas, other authors have studied the influence of iron content and dilution in the cladding on corrosion resistance properties.

In this scenario, the present work proposes, the development of an internal cladding process for riser pipelines with Nickel-based superalloy 625 via PTA welding process. An empirical evaluation was carried out in order to simulate as close as possible the real risers welding conditions in the field, taking into account all the variables in the process. The results are supported by metallographic analyzes, inspections by penetrating liquid and radiography, and analysis of chemical dilution by Energy Dispersive X-Ray Analysis (EDX).

\section{MATERIALS AND EXPERIMENTAL PROCEDURE}

For all the cladding tests on plate and on the inside of the risers, argon gas (Ar) was used as shielding gas, plasma gas and carrier gas. The substrate material of the riser used in the tests was the API 5L X70 steel. The atomized powder used as filler material is a Nickel-based superalloy commercially known as Inconel 625, with particle distribution between 45 and 125 micrometers.

The chemical compositions of the API 5L X70 substrate and the Nickel-based superalloy 625 powder, both given by the suppliers, are shown in Table 1 .

Table 1: Chemical composition of API 5L X70 substrate and Nickel-based superalloy 625 powder.

\begin{tabular}{ccccccccc}
\hline & \multicolumn{1}{c}{ API 5L X70 } & & & \\
\hline Element & $\mathrm{Fe}$ & $\mathrm{Mn}$ & $\mathrm{Si}$ & $\mathrm{C}$ & $\mathrm{Cu}$ & $\mathrm{V}$ & $\mathrm{Nb}$ & $\mathrm{Ni}$ \\
$\%$ wt. & 98.06 & 1.45 & 0.23 & 0.09 & 0.08 & 0.05 & 0.05 & 0.01 \\
\hline Element & $\mathrm{Cr}$ & $\mathrm{Mo}$ & $\mathrm{P}$ & $\mathrm{Al}$ & $\mathrm{Ti}$ & $\mathrm{S}$ & $\mathrm{Co}$ & \\
$\%$ wt. & 0.01 & 0.01 & 0.01 & 0.01 & 0.01 & 0.005 & 0.005 & \\
\hline
\end{tabular}

\begin{tabular}{ccccccccc}
\hline \multicolumn{10}{c}{ NICKEL-BASED SUPERALLOY 625 } \\
\hline Element & $\mathrm{Ni}$ & $\mathrm{Cr}$ & $\mathrm{Mo}$ & $\mathrm{Fe}$ & $\mathrm{Nb}+\mathrm{Ta}$ & $\mathrm{Ti}$ & $\mathrm{Al}$ & $\mathrm{Si}$ \\
$\%$ wt. & Balance & 22.30 & 8.50 & 2.80 & 3.50 & 0.10 & 0.10 & 0.15 \\
\hline Element & $\mathrm{Mn}$ & $\mathrm{Co}$ & $\mathrm{C}$ & & & & \\
$\%$ wt. & 0.10 & 1.00 & 0.03 & & & & & \\
\hline
\end{tabular}


The welding tests and their respective analyzes were divided into two stages. The first stage was intended for the preliminary parameterization of the PTA welding process on plate. Two procedures were used, with $5 \mathrm{~mm}$ and $11 \mathrm{~mm}$ of weaving amplitude, called here $\mathrm{C} 1$ and $\mathrm{C} 2$, respectively.

The claddings were subjected to metallographic analysis to calculate the geometric dilution, as shown in Equation 1 and Figure 1. The metallography consisted of preparing the weld bead cross section, followed by sanding, polishing and etching with $5 \%$ Nital for 3 seconds.

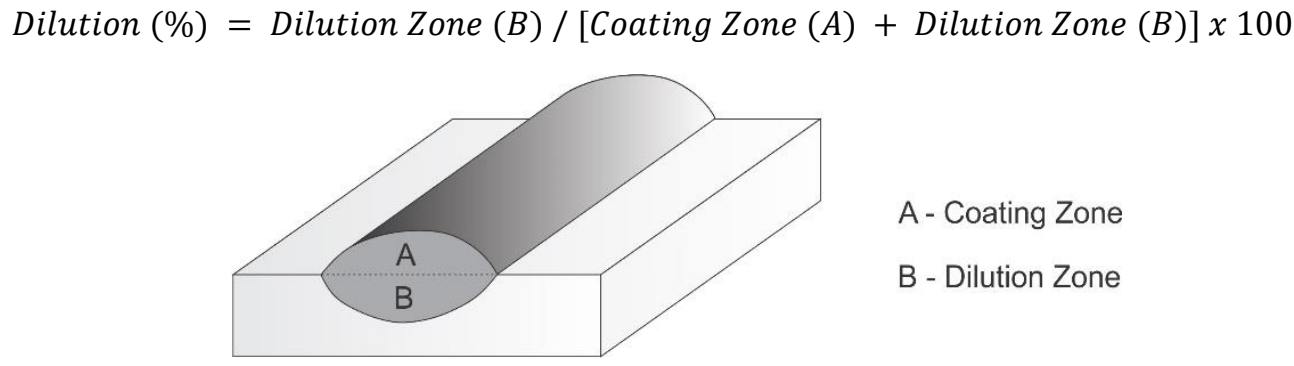

Figure 1: Weld bead regions considered for calculating geometric dilution.

Besides, inspections by penetrating liquid and radiography were performed, confirming the exemption of internal and surface defects in the claddings. Then, after finding satisfactory parameters for cladding on plate, cladding tests were carried out inside the risers, making the necessary adaptations to the parameters.

The obtained claddings were then sectioned again and in a similar way to claddings on plate, the presence of discontinuities on the surface and inside the cladding were evaluated, followed by an additional stage of chemical composition analysis via EDX.

\section{RESULTS AND DISCUSSIONS}

The results and their respective discussions are divided into two sections, the cladding tests conducted on sheet metal and the internal risers cladding tests.

\subsection{Definition of Preliminary Welding Parameters}

In order to achieve welding parameters for application in internal risers cladding, preliminary cladding on plate tests were carried out. The aim was to find empirically two similar welding parameters but that differed in terms of the welding area covered by one weld bead. The two different procedures, $\mathrm{C} 1 \mathrm{and} \mathrm{C} 2$, with $5 \mathrm{~mm}$ and $11 \mathrm{~mm}$ of weaving amplitude, respectively can be seen in Figure 2.
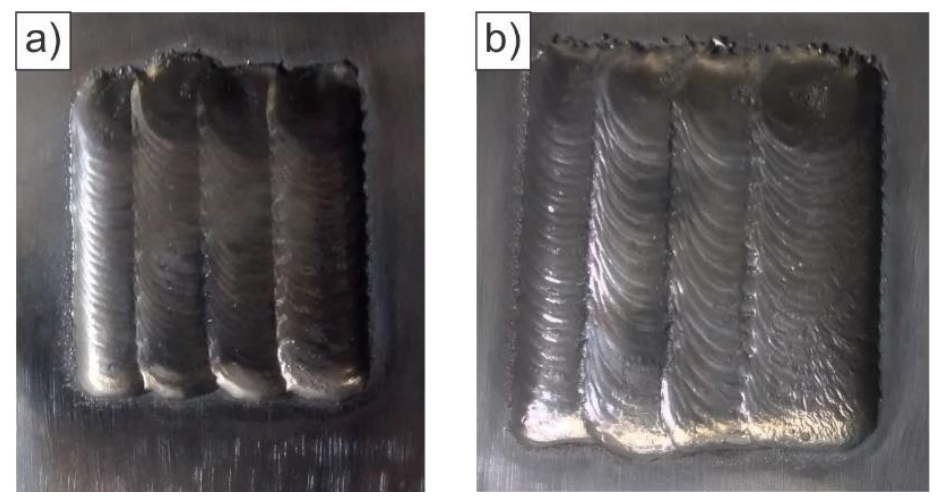

Figure 2: Coating tests on plate a) $\mathrm{C} 1$ and b) $\mathrm{C} 2$ on plate.

For this purpose, the existence of defects in the surface and in the interior of the cladding were evaluated, as well as the dilution levels of the two cladding scenarios $\mathrm{C} 1$ and $\mathrm{C} 2$. The cross sections of claddings $\mathrm{C} 1$ and $\mathrm{C} 2$ can be seen in Figure 3. 


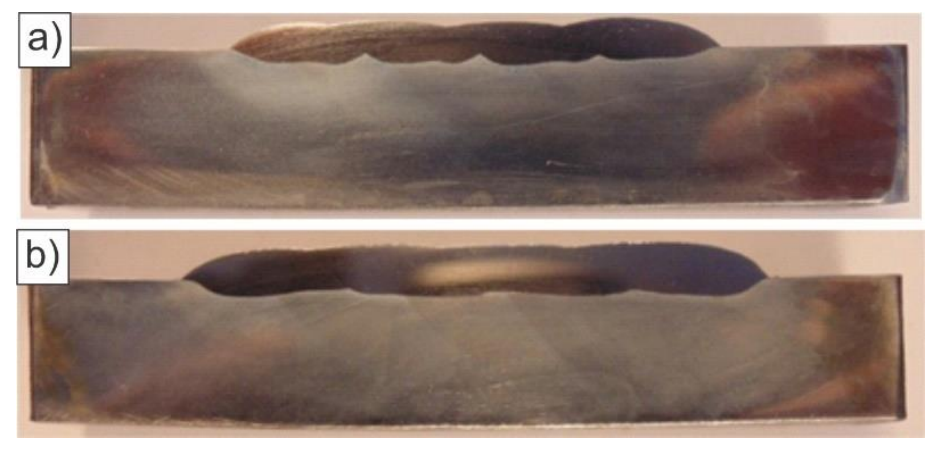

Figure 3: Cross sections of cladding after 5\% Nital etching, without any image magnification, on plate a) $\mathrm{C} 1$ and b) $\mathrm{C} 2$.

During the welding process of cladding on plate, it was found the need to clean the substrate surface before welding, in order to facilitate the opening and maintenance of the electric arc, in addition to avoiding contamination of the melting pool by oxidation or impurities found on the substrate surface.

A satisfactory process was obtained for the two proposed scenarios (Figure2), with the parameters shown in Table 2.

Table 2: Preliminary welding parameters used in the $\mathrm{C} 1$ and $\mathrm{C} 2$ cladding tests.

\begin{tabular}{ccc}
\hline & C1 & C2 \\
\hline Weaving Amplitude $(\mathrm{mm})$ & 5 & 11 \\
Weaving Frequency (Hz) & 0.4 & 0.4 \\
Current (A) & 110 & 130 \\
DBP (mm) & 10 & 10 \\
Shielding Gas Flow (1/min) & 12 & 12 \\
Plasma Gas Flow (1/min) & 4 & 4 \\
Carrier Gas Flow (1/min) & 2.5 & 2.5 \\
Deposition Rate (kg/h) & 0.7 & 0.7 \\
Welding Speed (cm/min) & 7 & 7 \\
Height of the Reinforcement (mm) & 2.8 & 2.9 \\
\hline
\end{tabular}

After the welding, analyzes of geometric dilution, measurement of widths and minimum and maximum heights of the reinforcements of the claddings were carried out. Table 3 shows the geometric results achieved.

Table 3: Geometric results obtained from $\mathrm{C} 1$ and $\mathrm{C} 2$ cladding tests.

\begin{tabular}{ccc}
\hline & C1 & C2 \\
\hline Geometric Dilution $(\%)$ & 13 & 16 \\
Weld Bead Width (mm) & 8 & 13 \\
Minimum Reinforcement Height $(\mathrm{mm})$ & 2.5 & 2.6 \\
Maximum Reinforcement Height $(\mathrm{mm})$ & 2.7 & 2.9 \\
\hline
\end{tabular}

Besides the geometric analyzes, inspections were carried out by penetrating liquid and radiography, according to the ASME 2007 section IX criteria. The results showed the absence of defects in the overlapping of the weld beads and the proper fusion with the substrate. The results of both inspections, penetrating liquid and radiography, can be seen in Figure 4 and Figure 5, respectively. 

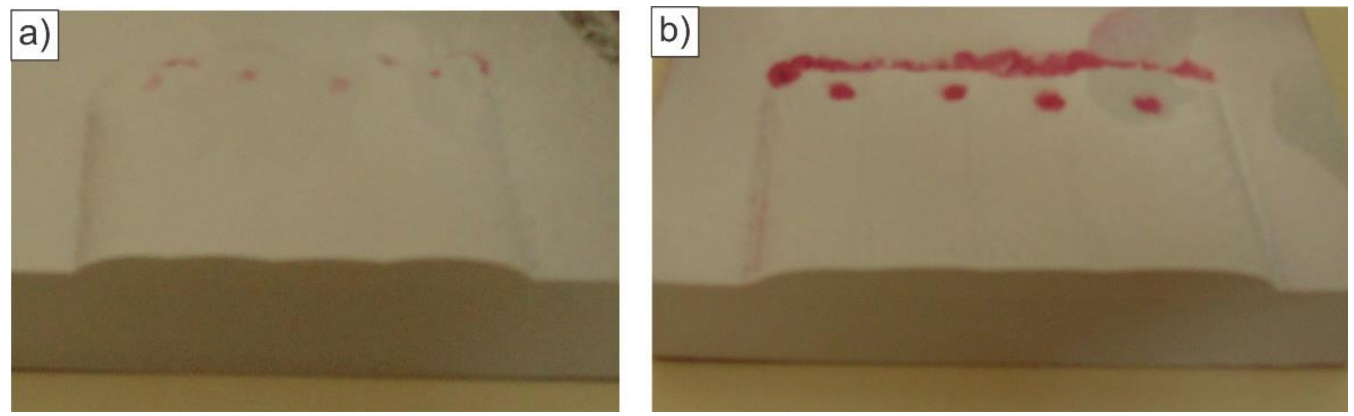

Figure 4: Penetrating liquid inspection of claddings a) $\mathrm{C} 1$ and b) $\mathrm{C} 2$.
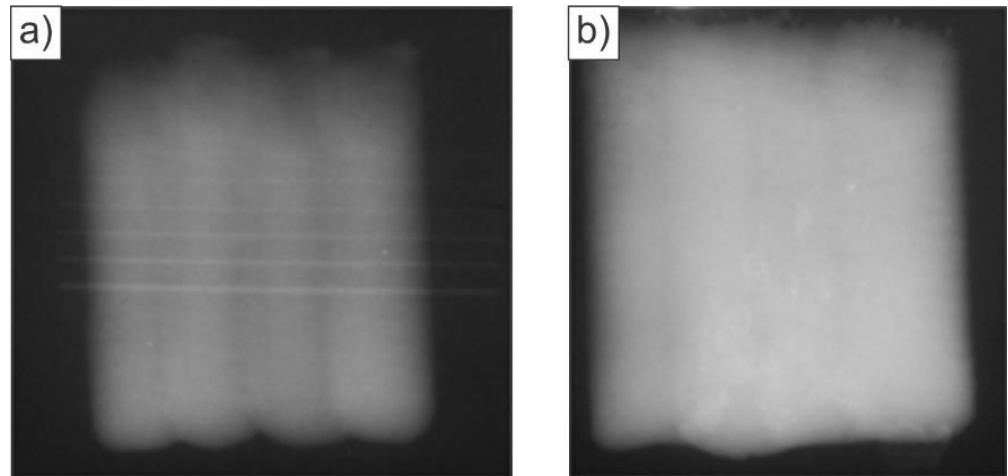

Figure 5: Radiographic inspection of claddings a) $\mathrm{C} 1$ and b) $\mathrm{C} 2$.

\subsection{Internal Riser Cladding}

According to the proposed methodology, the inside of the riser to be cladded was previously cleaned. The difficulty of cleaning with abrasive discs with a hand tool led to the procedure being carried out through machining. Figure 6 shows the internal appearance of the riser, before and after machining.
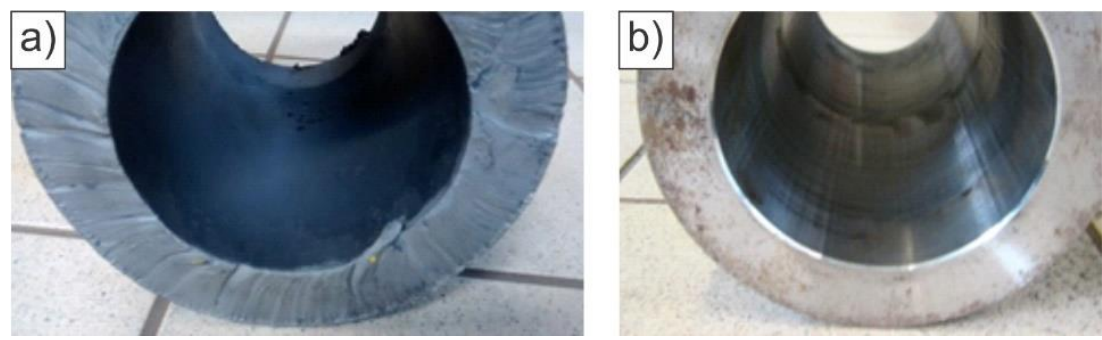

Figure 6: Interior of the riser a) before e) after machining to clean oxidation and impurities.

Using the parameters adopted as satisfactory for $\mathrm{C} 1$ and $\mathrm{C} 2$ claddings, welding tests were carried out inside the riser, initially cut to $250 \mathrm{~mm}$ in length. The C2 internal cladding test performed can be seen in Erro! Fonte de referência não encontrada.. 


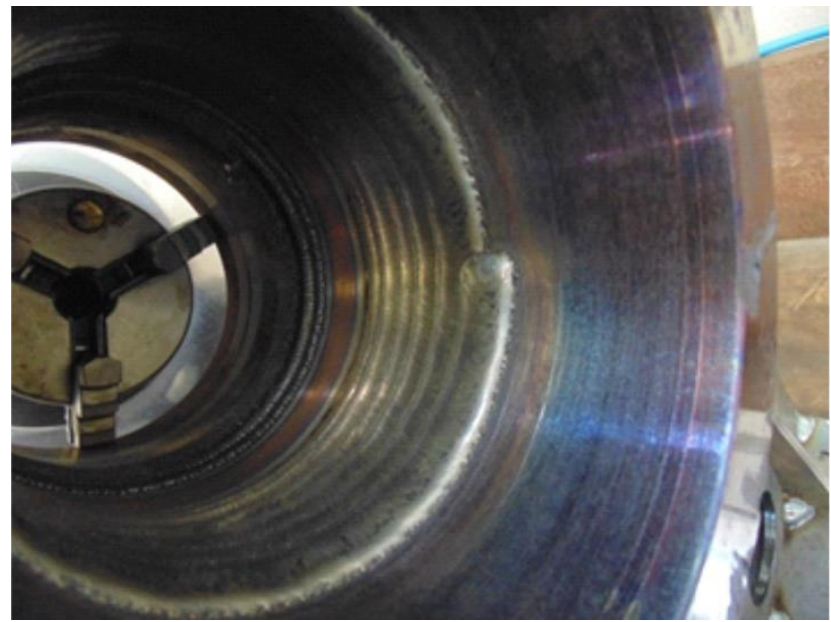

Figure 7: Internal cladding test C2.

In the first welding test carried out inside the riser, the weld bead showed differences in its geometry when compared to flat plate welding. Due to the greater volume of material and thickness of the riser, for the same electrical current the weld bead has a more convex profile than in flat plate caused by the difference in heat dissipation. Therefore, the parameters used initially, $\mathrm{C} 1$ and $\mathrm{C} 2$ had to be changed, with a large increase in electrical current to resolve the issue of high convexity.

During the welding, non-uniform heating and cooling in weld metal and in base metal generates harder Heat Affected Zone (HAZ), cold crack susceptibility and residual stress [29]. Therefore, to minimize the effects of this thermal cycle, a preheating of the riser of $100{ }^{\circ} \mathrm{C}$ was implemented in the process before welding. The adapted parameters are shown in Erro! Fonte de referência não encontrada..

Table 4: Welding parameters optimized for internal cladding procedures $\mathrm{C} 1$ and $\mathrm{C} 2$.

\begin{tabular}{ccc}
\hline & C1 & C2 \\
\hline Current (A) & 210 & 200 \\
DPB (mm) & 12 & 12 \\
Shielding Gas Flow (L/min) & 12 & 12 \\
Plasma Gas Flow (L/min) & 3 & 3 \\
Carrier Gas Flow (L/min & 2.5 & 2.5 \\
Deposition Rate (kg/h) & 1.34 & 1.34 \\
Welding Speed (cm/min) & 9 & 7 \\
Weaving Amplitude $(\mathrm{mm})$ & 5 & 11 \\
Weaving Frequency $(\mathrm{Hz})$ & 0.4 & 0.4 \\
Distance Between Weld Beads $(\mathrm{mm})$ & 8 & 13 \\
Preheating Temperature $\left({ }^{\circ} \mathrm{C}\right)$ & 100 & 100 \\
\hline
\end{tabular}

From the cladding tests carried out on risers of greater length, it was found that the risers overheated, reaching temperatures higher than $350^{\circ} \mathrm{C}$. The high temperature caused an excessive runoff of the melting pool and a significant change in the powder feeding behavior.

The overheating in this test is justified by the reduced instantaneous speed of the welding torch, in view of the high value of the used weaving amplitude, and consequently of the lower welding speed.

Welding procedures with lower values of fabric width favor a better thermal distribution of the equipment to be coated, preventing its overheating. In this scenario, tests were carried out on the internal cladding of the riser with fillet weld beads, i.e., without lateral oscillation of the welding torch, called here C3. The welding parameters used are shown in Table 5. 
Table 5: Welding parameters optimized for C3 internal cladding procedure.

\begin{tabular}{cc}
\hline & C3 \\
\hline Current (A) & 230 \\
DPB (mm) & 12 \\
Shielding Gas Flow (L/min) & 12 \\
Plasma Gas Flow (L/min) & 3 \\
Carrier Gas Flow (L/min & 2.5 \\
Deposition Rate (kg/h) & 1.34 \\
Welding Speed (cm/min) & 14 \\
Weaving Amplitude (mm) & - \\
Weaving Frequency (Hz) & - \\
Distance Between Weld Beads (mm) & 6 \\
\hline
\end{tabular}

As previously mentioned, when the weaving amplitude is smaller, it is possible to use a higher welding speed. In contrast, what are obtained are narrower weld beads, requiring a greater amount of weld beads.

The claddings obtained through the use of the three welding torch movement modes $(\mathrm{C} 1, \mathrm{C} 2$ and $\mathrm{C} 3)$, were then sectioned and their geometric dilution was evaluated, analogously to the cladding on plate. The results of the geometric dilutions are shown in Table 6.

Table 6: Geometric dilution of internal cladding performed by procedures $\mathrm{C} 1, \mathrm{C} 2$ and $\mathrm{C} 3$.

\begin{tabular}{cccc}
\hline Cladding Testing & $\mathrm{C} 1$ & $\mathrm{C} 2$ & $\mathrm{C} 3$ \\
Geometric Dilution $(\%)$ & 18.1 & 26.7 & 15.2 \\
\hline
\end{tabular}

Besides that, in order to complete the measurement of the dilution more precisely, mainly regarding the chemical composition of the element Iron in the cladding, the samples were taken to EDX (Energy Dispersive X-Ray Detector). The results are plotted in graphics and each colored line represents a chemical element analyzed (Chromium, Molybdenum, Nickel and Iron). Chemical analyzes of the claddings C1, C2 and C3 can be illustrated in Figure 8, Figure 9 and Figure 10, respectively.

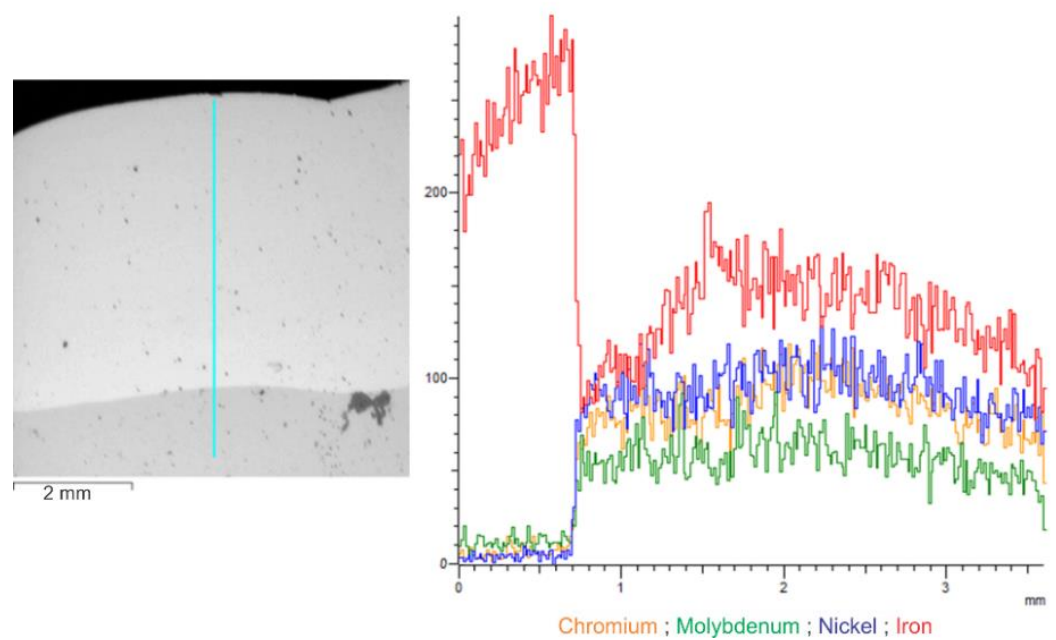

Figure 8: Chemical composition analysis of $\mathrm{C} 1$ cladding via EDX. 

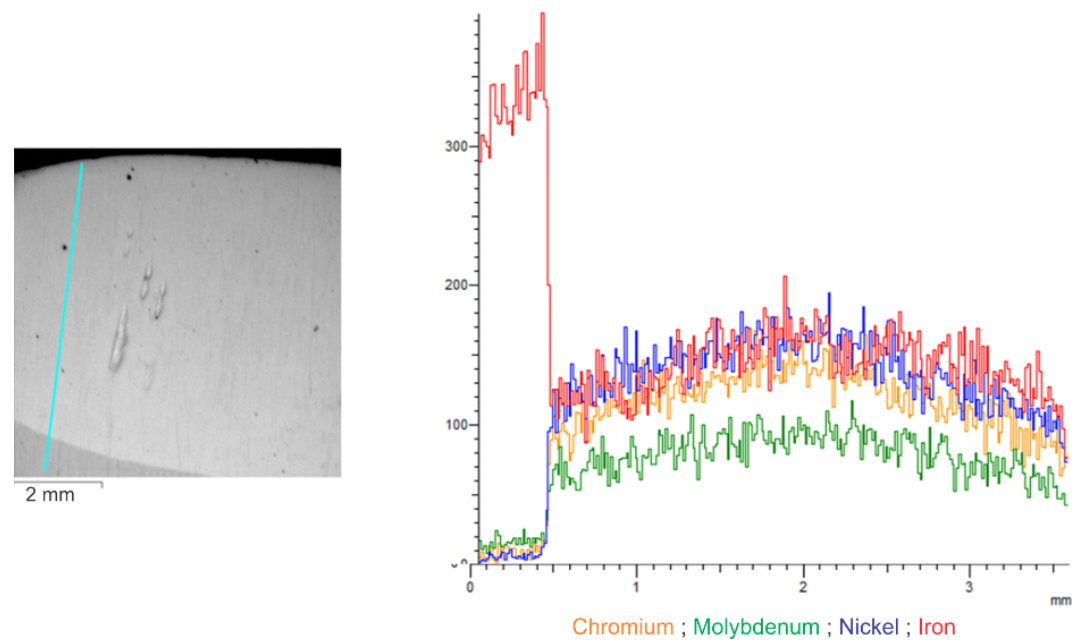

Figure 9: Chemical composition analysis of $\mathrm{C} 2$ cladding via EDX.
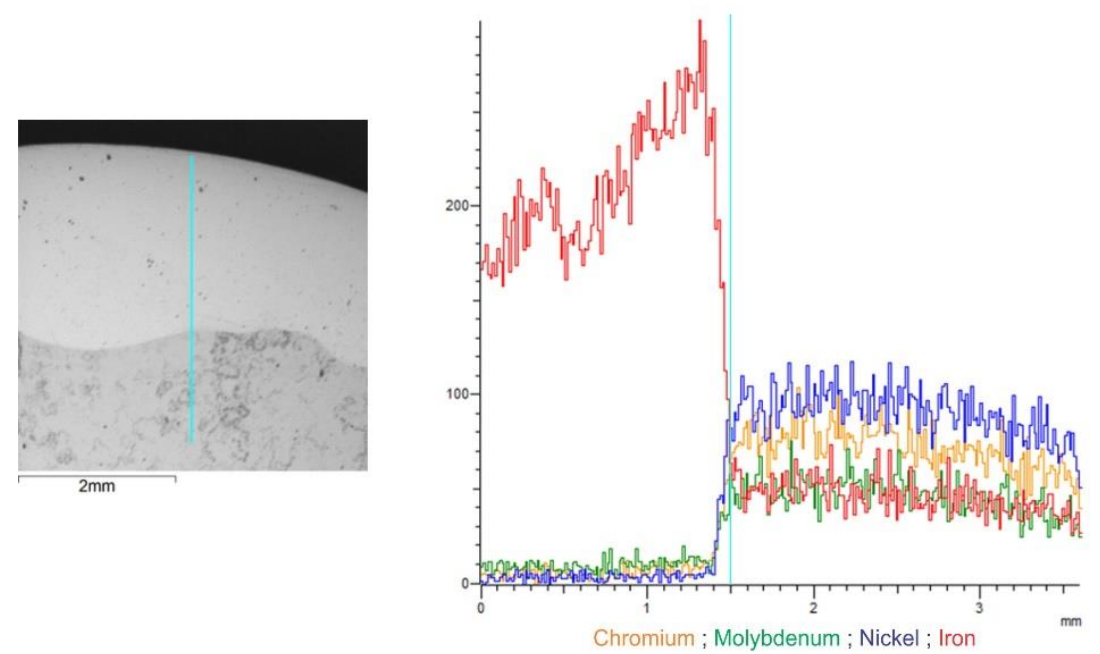

Figure 10: Chemical composition analysis of $\mathrm{C} 3$ cladding via EDX.

From the results obtained from chemical composition, it is possible to stand that, in all parameters $\mathrm{C}$, $\mathrm{C} 2$ and $\mathrm{C} 3$, the Iron content decreases abruptly when the other elements content rise, marking the border between the base metal (riser), rich in Iron, and the cladding, rich in nickel, chromium and molybdenum providing the corrosion resistance characteristic.

Analogous to cladding on plate, inspections were carried out by penetrating liquid and radiography, seeking confirmation of defects in the deposition and overlapping of the weld beads. It is possible to verify in Figure 12 that the cladding did not present defects such as pores and cracks, being approved according to ASME IX. The inspections results are shown in Figure 11. 

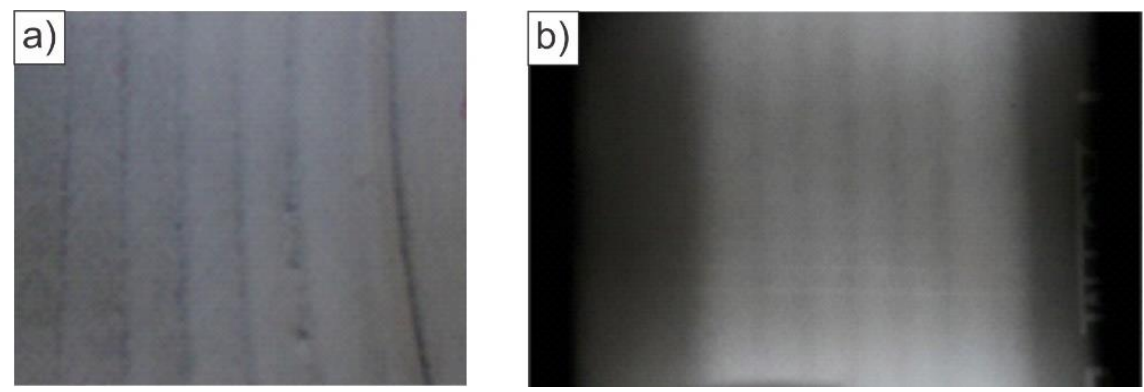

Figure 11: Inspections by a) penetrating liquid and b) radiography of the $\mathrm{C} 3$ internal cladding.

Finally, the three scenarios $(\mathrm{C} 1, \mathrm{C} 2$ and $\mathrm{C} 3)$ used were evaluated comparatively based on their productivity for internal cladding of 1 meter of riser. Using the weld speed and the weld bead width it was possible to calculate the time needed to coat 1 meter of riser and consequently the amount of gas and Inconel 625 powder required. The comparison is shown in Erro! Fonte de referência não encontrada. Thus, with the results found, the $\mathrm{C} 3$ welding parameters proved to be more suitable, both from an economic point of view, being faster and consuming less consumables, as well as operational, since the fillet welding presented advantages in terms of less riser overheating and also less dilution when compared to $\mathrm{C} 1$ and $\mathrm{C} 2$.

Table 7: Productivity evaluation of $\mathrm{C} 1, \mathrm{C} 2$ and $\mathrm{C} 3$ cladding procedures for internal cladding of 1 meter of riser.

\begin{tabular}{cccc}
\hline & \multicolumn{3}{c}{ 1 Meter Cladding } \\
\hline & C1 & C2 & C3 \\
\hline Welding Time (h) & 7.5 & 7.95 & 5.55 \\
Total Powder Consumption (kg) & 10.05 & 10.653 & 7.44 \\
Total Gas Consumption (l) & 7875 & 8347.5 & 5827.5 \\
\hline
\end{tabular}

\section{CONCLUSIONS}

This paper empirically evaluated the development of a PTA welding process for the purpose of internal riser cladding. From the results obtained, it was possible to conclude that the PTA welding process allows to achieve the metallurgical and operational benefits necessary for an application of internal cladding of equipment and structures. The claddings performed were free from internal and surface defects in the weld beads, which were evaluated by penetrated liquid and radiography.

It was observed that welding procedures with lower values of fabric width favor a better thermal distribution of the equipment to be coated, preventing its overheating. Thus, the procedure that showed the best results was $\mathrm{C} 3$, performed with filleted weld beads. In addition to the inspections results, procedure $\mathrm{C} 3$ presented significant operational advantages in relation to productivity, such as, for example, a reduction in the time required to cover 1 meter of riser of $25.9 \%$ and $30.2 \%$ compared to procedures $\mathrm{C} 1$ and $\mathrm{C} 2$, respectively.

\section{REFERENCES}

[1] SILVA, R.H.G., RIFFEL, K.C., CARVALHO, L.P., et al., Double-Sided Welding as an Alternative for Joining Internally Clad Pipes. Journal of Pipeline Systems Engineering and Practice. Doi 10.1061/(ASCE)PS. v. 11, pp. 1949-1204.0000452, 2020.

[2] PORTAL BRASIL. 2017. "Petrobras produced 2.7 million barrels of oil per day in August." http://www.brasil.gov.br /economia-e-emprego/2017/09/petrobras-produziu-2-7-milhoes-de-barris -depetroleo-por-dia-em-agosto. Accessed March 11, 2019.

[3] JESUS, F.D., SILVA J.F., ROITMANN T. "Industrial policy and local content: Brazil's pre-salt area case.” In Proc., Offshore Technology Conf. Houston: Offshore Technology Conference. 2017

[4] AZEVEDO FILHO, E.T., PALMA, M.A.M., PERESTRELO, M., et al., The pre-salt layer and challenges to competitiveness in Brazil: Critical reflections on the local content policy in the oil and gas Sector the Extractive Industries and Society, 2019. DOI: https://doi.org/10.1016/j.exis.2019.09.009.

[5] ANTUNES, R.A., MACHADO, C.A.V.A., CORREA, O.V. "Influence of testing temperature on the cor- 
rosion behavior of API 5L X70 pipeline", In: 22nd International Congress of Mechanical Engineering (COBEM), pp. 3252-3256, Ribeirão Preto, Nov. 2013

[6] EKA PUTRA, I.W., FUADDIN, N.A.H., MAZLI, A.M. "Corrosion resistance alloy lined pipe seal weld assessment using finite element analysis and full scale qualification testing for high pressure and high temperature pipeline application." In Proc., Offshore Technology Conf. Houston: Offshore Technology Conference. 2018.

[7] OLAKANMI, E.O., NYADONGO, S.T., HOOSIAN, S., et al., Consolidation mechanism, microstructural evolution and corrosion resistance of Inconel 625 coatings. Surface Engineering, 2020. DOI: https://doi.org/10.1080/02670844.2020.1783746.

[8] AL-FADHLI, H.Y., STOKES, J., HASHMI, M.S.J. The erosion-corrosion behaviour of high velocity oxy-fuel (HVOF) thermally sprayed inconel-625 coatings on different metallic surfaces. Surface and Coatings Technology, v. 200, pp. 5782-5788, 2006.

[9] DINGAPG, D., MAZUMDERJ. Laser Aided Direct Metal Deposition of Inconel 625 Superalloy: Microstructural Evolution and Thermal Stabibility. Materials Science and Engineering, 2009. DOI: doi:10.1016/j.msea.2009.01.009.

[10] LORENZONIRA, G., SANTOS, A.C. A study on the intergranular corrosion and pitting resistance of Inconel 625 coating by PTA-P. Engineering Science Technology, DOI: doi:10.1080/1478422X.2018.1533677. v. 54, pp. 62-74, 2019.

[11] KIM, H.-I., PARK, H.-S., KOO, J.-M., et al., Welding characteristic evaluation of GMAW and laser cladding for the gas turbine 1st blade. Key Engineering Materials, DOI: doi:10.4028/www.scientific.net/KEM.353-358.519. pp. 519-522, 2007.

[12] SANTOS, A.X.M., COSTA, J.D., SAUSA, M.B., et al., Study on Influence of the PTA-P Welding Process Parameters on Corrosion Behavior of Nickel-based super-alloy 625 Coatings. Revista Materia, DOI: https://doi.org/10.1590/s1517-707620190001.0619. v. 24, 2019.

[13] FERREIRA, L.S.; GRAF, K., SCHEID, A., Microstructure and Properties of Nickel-based C276 Alloy Coatings by PTA on AISI 316L and API 5L X70 Steel Substrates. Materials Research. Vol. 18, Jan/Feb 2015. https://doi.org/10.1590/1516-1439.332914

[14] SMITH, L. Control of corrosion in oil and gas production tubing. In: Proceedings of the Materials Congress 98; 1998; Cirencester, Uk. Cirencester, UK; 1998.

[15] MANKINS, W.L., LAMB, S. Nickel and nickel alloys. In: ASM International. Properties and selection: nonferrous alloys and special-purposed materials. Ohio: Materials Park; 1990. pp. 1363-1403.

[16] LIYANAGE, T., FISHER, G., GERLICH, A.P., Microstructures and abrasive wear performance of PTAW deposited Ni-WC overlays using different Ni-alloy chemistries. Wear. 2012; http://dx.doi.org/10.1016/j.wear.2011.10.001. pp. 274-275:345-354.

[17] GURUMOORTHY, K, KAMARAJ, M, RAO, K.P. et al., Microstructure and wear characteristics of nickel based hardfacing alloys deposited by plasma transferred arc welding. Materials Science and Technology. http://dx.doi.org/10.1179/174328406X100734., v. 22, n. 8, pp. 975-980, 2006.

[18] BOND D., D'OLIVEIRA, A.S.C.M., Effect of current and atomized grain size distribution on the solidification of Plasma Transferred Arc coatings. Materials Research. https://doi.org/10.1590/S151614392012005000101, v. 15, Aug 2012.

[19] DÍAZ, V.M.V., Equipment Innovation and Evaluation of the Powder Powered Transferred Plasma Process (PTAP) for Welding Out of Position.198 f. Tese (Doc in Engineering) - Universidade Federal de Santa Catarina, Florianópolis. 2005.

[20] PAVLENKO, A. New knowledge about the physical basics of plasma powder deposition as the basis for process control.118 f. (Doc in Engineering) - Rheinisch-Westfälisch Technisch Technisch Hochschule Aachen. 1996.

[21] MENON, R., MOSIER, W.C., Stainless Steel with Improved Weldability and Cavitation Resistance, CONSOLDA, 1996

[22] RIBEIRO, H.O. Development of Alloys for Cavitation Resistant PTA Coatings. $167 \mathrm{f}$. Tese (Doc in Engineering) - Universidade Federal de Santa Catarina. 2007

[23] DEUIS, R.L. et al. Metal-matrix composite coatings by PTA surfacing. Composites Science and Technology, v.58, n. 2, p. 299-309, 1998

[24] GUAN, T., CAO, M., Microstructure and Wear Resistance of Zrc-ZrB2 / Ni Composite Coatings Pre- 
pared by Plasma Transferred Arc Cladding. Materials Research. https://doi.org/10.1590/1980-5373-mr-20180781, v. 22. May 2019.

[25] GOMES, R., HENKE. S., D'OLIVEIRA, A.S., Microstructural controlo of Co-based PTA coatings. Materials Research. https://doi.org/10.1590/S1516-14392012005000099, v. 15. Aug 2012.

[26] SILVA, R.H.G., DUTRA, J.C., PTA-P Process - A Literature Review as a Basis for Innovations. Part 1 of 2: Building Elements. Soldagem e Inspeção, v. 17, n. 1, Jan/Mar 2012.

[27] SILVA, R.H.G.; DUTRA, J.C., PTA-P Process - A literature review as a basis for innovations: part 2 of 2: thermal and kinematic behavior of the powder, process parameters and consumables. Soldagem e Inspeção [online]. ISSN 0104-9224., v.17, n.2, pp. 173-183, 2012.

[28] GATTO, A., BASSOLI, E., FORNARI, M. Plasma Transferred Arc deposition of powdered high performances alloys: process parameters optimisation as a function of alloy and geometrical configuration. Surface \& Coatings Technology, v. 187, p. 265-271, 2004.

[29] SRIVASTSVA, B.K. A Review on Effect of Preheating and/or Post Weld Heat Treatment (PWHT) on Mechanical Behaviour of Ferrous Metals. International Journal of Engineering Science and Technology, v. $24,2010$.

\section{ORCID}

Régis Henrique Gonçalves e Silva http://orcid.org/0000-0003-0660-6495

Rafael Gomes Nunes Silva http://orcid.org/0000-0003-4208-679X

Júlia Moraes Dornelles https://orcid.org/0000-0002-3204-4185

Fernando Costenaro Silva https://orcid.org/0000-0003-3110-2248 